\title{
Epistles of the Brethren of Purity. On Arithmetic and Geometry: An Arabic Critical Edition and English Translation of EPISTLES 1 \& 2
}

Nader El-Bizri, ed. and trans.

Oxford, NY: Oxford University Press in association with the Institute of Ismaili Studies, 2012. 400 pages.

The significance of the epistles on a range of intellectual disciplines by the group of scholars known as the Brethren of Purity (Ikhwan al-Safa') has been known for some time, although one might argue that their significance for a proper assessment of Islamic intellectual history has been neglected. The 
book under review is part of an exciting new project initiated by the Institute of Ismaili Studies in London to re-edit the whole text with critical analytical translations and annotations undertaken by a number of specialists around the world. For those of us who specialize in Islamic intellectual history and need texts to use in the classroom, this is an excellent and most welcome development. The companion volume edited by el-Bizri, which attempts not only to make sense of who the Ikhwan were but also to assess their impact, demonstrates that their significance was recognized by later traditions even when it was occluded. One small quibble - it would have been good to see the Arabic and English on facing pages, which may have been logistically problematic. As it is, it makes the comparison of the original text with the English a bit more difficult.

The two epistles translated here are the first in the sequence and constitute part of the first section of the Rasá' $i l$ on the mathematical and propaedeutical sciences (al-'ulūm al-riyādìyah al-ta 'ìmīyah). Nader el-Bizri, the translator and editor of the series, is a historian of philosophy and science in the Islamic world and has recently been focusing on the history of geometry, mathematics, and optics and publishing widely on Ibn al-Haytham (d. 1040). These two epistles form part of the ancient quadrivium that constituted a more advanced stage of study associated with Boethius (d. 524) and was based upon the mathematics of Nicomachus of Gerasa, a Neopythagorean of the first century $\mathrm{CE}$ : training in arithmetic, geometry, music, and astronomy were considered to be the very heart of a scientific education. After the first two epistles, epistle 3 deals with astronomy, epistle 4 with cosmography, epistle 5 with music, and epistle 6 with proportions (that ties the quadrivium together) - and that is before they move onto the next set of propaeduetics, namely the logical organon beginning with epistles 7 and 8 (the theoretical and practical arts) that provide a classification of the sciences on which the approach to holism is based.

From these latter epistles, we can clearly see where the Ikhwan differ from their contemporaries who had a greater impact on later Islamic philosophy, such as al-Farabi. El-Bizri provides a scholarly introduction that locates the Ikhwan's work in the historical context of the creative school of Baghdad, which developed the mathematical ideas of Nicomachus and the wider tradition associated with Archimedes of Syracuse (d. 212 BCE) and Apollonius of Perga (d. $190 \mathrm{BCE}$ ). The author analyzes the contents of the epistles (he does a sterling job of tracing influences and noting the lacunae thereof) and comments on the manuscript tradition and the process of editing and translating. The introduction and the translations are well supported by a scholarly anno- 
tation that indicates lines of research for those interested in pursuing them. His own taste for Ibn al-Haytham is clear - and he points out some of the gaps in the Ikhwan's work, notably the neglect of algebra that was well established through the work of al-Khwarazmi and Qusta ibn Luqa's reception of the arithmetic of Diophantus of Alexandria (third century $\mathrm{CE}$ ).

The epistles' explanatory summary focuses on the historical contextualization of the ideas - but only briefly touches upon the question of the Neopythagorean influence of theological and mathematical mysticism. However, he does suggest that there might be a link with Iamblichus' (d. 325) approach to mathematics, philosophy, and mysticism. If there were any evidence (finding Iamblichus in Arabic is notoriously difficult, apart from possibly the commentary on the so-called Golden Verses and perhaps some docta in the doxographical literature), it would be worth engaging. El-Bizri also suggests that the approach to mathematics is more Platonist than Pythagorean - again one would like to learn what that means. The conceptualization of the relationship of mathematics to metaphysics to natural philosophy seems to be based on the homologies between the human as the microcosm and nature as the macrocosmic manifestation of the human; however, this certainly needs some further analysis as most previous specialists on the Ikhwan have stressed the importance of this theme.

The epistle on geometry draws heavily upon Euclid - as one would expect, and we know his work became canonical throughout the empire - as well as Pythagorean readings of works such as Plato's Timaeus. It also indicates other applications of geometry, such as magic, and refers to epistle 52 (which has already been translated and published in the current series). Given the Ikhwan's commitment to theosis, the notion that the practice of philosophy as a way of living entails a desire to become "god-like" (the locus classicus is in Plato's Theaetetus 176), it would be interesting to see how that relates to their consideration of mathematics.

A further interesting question for historians looking for the transmission of ideas and networks would be to consider whether the epistles' organization and constitution actually denoted the pedagogy and curriculum for a group of thinkers in southern Iraq at that time. And if that were the case, did it die out because of the success of alternative methodologies and pedagogies at the imperial center in Baghdad?

The introduction to each epistle shows an awareness of how the sciences link together to form an epistemic whole and the role of the two particular disciplines within that process. Epistle 1 begins with a statement that the Ikhwan seek to study all of the sciences that pertain to existent things (mawjū $\bar{a} t)$ and 
into their arrangement, order, and principles. One has to start with the propaedeutics, and the first step is arithmetic (using a transliteration of the Greek term), on the path to acquiring wisdom following the Pythagorean way. Given this last statement, the translator might have wished to comment further on this. The classic fourfold division of the sciences follow - propaedeutics (arithmetic, geometry, music, and astronomy), logic, the natural sciences, and the theological-metaphysical sciences. This arrangement of the Ras $\bar{a}^{\prime} i l$, on the whole, is prefaced by a key statement about the nature of this quest:

The beginning of philosophy is the love of the sciences, the middle of it is the knowledge of the true nature of existent things by virtue of human ability and the end is speech and action that is in accord with knowledge. (p. 66)

That is to say: One begins with a desire to learn, then acquires a theoretical understanding of reality, and then acts ethically based upon what one knows. I would therefore take issue with part of this phrase translated - the phrase $b i$ hasab al-țaqqati al-basharīyah should be "insofar as is humanly possible" as this standard formulation of the limits of knowledge goes back to the ancients. The epistle's remaining twenty-three chapters deal with different aspects of the Ikhwan's number theory.

The epistle on geometry, broadly based on Euclid's Elements, is divided into twenty-seven chapters. Although the earliest translation of Elements seems to have been completed by the early ninth century, the translations of Hunayn ibn Ishaq (d. 873) and Thabit ibn Qurra (d. 901) were probably the ones available to the Ikhwan. The introduction to this epistle repeats the description of the propaedeutics and defines geometry as the "science that inquires about magnitudes, distances, and the quantity of their kinds" (p. 104).

Although much of the epistle deals with axioms and their like, a few chapters stand out for their implications on applications and also on a more reflective approach to geometry. Chapter 15, on surveying, explains why the theoretical study of geometry is useful in the wider world. Chapters 16 and 17 stress the need for a collaborative approach to studying the sciences in order to avoid errors that might arise from individual calculations. Collaboration for the good is necessary for humans to transcend the illness and crisis that they face in this world due to "the offence committed by our father Adam":

To secure your success and salvation from this world, which is the realm of generation and corruption, and from the sufferings of hell and the company of demons and Iblis's soldiers, and by way of ascending to the domain of the celestial spheres and the vastness of the heavens, to the abode of the lofty 
ones, and by way of neighbouring the angels of the Compassionate One who abide in His proximity, you need the help of those who are brothers to you, who are counsellors to you and virtuous friends, and who are knowledgeable about the articles of the faith and are knowers of the truths of things ... They will guide you on the pathway of the afterlife and the way to reach it, in order to be saved from what has entrapped us all because of the offense of our father Adam! (pp. 138-39)

The echoes of the Platonic tradition, especially the first chapter (mimar) of Theologia Aristotelis, on this text seem very clear - as well as the explicit reference that follows to Kalīlah wa Dimnah, another major cultural artifact of the time. The epistle's final two chapters indicate further uses of geometry: Given that numbers and their arrangements and quantities effect the soul, they briefly describe the use and construction of talismanic squares and refer the reader to epistle 52 for further detail. So in some ways the propaedeutics already refer the initiate to magic, which is part of the theological and metaphysical sciences that lie at the culmination of one's education.

Overall, this volume is a major contribution to Islamic intellectual history - scholarly, supported, and judicious. The translation on the whole is fluent one might quibble some of the renditions, but this reviewer did not spot many egregious errors - and the edition and its principles are clear. 